\title{
Soft Tissue Sarcoma of the Trunk and Extremities cM1 TNM Finding v8
}

National Cancer Institute

\section{Source}

National Cancer Institute. Soft Tissue Sarcoma of the Trunk and Extremities CM1 TNM

Finding v8. NCI Thesaurus. Code C136678.

Soft tissue sarcoma of the trunk and extremities with distant metastasis. (from AJCC 8th Ed.) 